\title{
RECEPTIVENESS OF ISLAMIC HOME FINANCING AMONG MALAYSIANS: A REVISIT
}

\author{
Khadijah Muhammad Sayuti * \\ Universiti Malaysia Sabah
}

\author{
Hanudin Amin \\ Universiti Malaysia Sabah \\ Dzuljastri Abdul Razak \\ International Islamic University Malaysia \\ Hamid Rizal \\ Universiti Malaysia Sabah
}

\begin{abstract}
This study examines the effects of the key factors influencing the intention of first-time house buyers to choose Islamic home financing products. First-time house buyers are selected since they are the major segment of Islamic banks' profit for the Islamic mortgage sector. Drawing upon the theory of planned behaviour (TPB), this study proposes a model to test the effects of attitude, subjective norm and perceived behavioural control on the intention of selecting Islamic home financing. This study also examines the effect of "perceived customer taqwa" on customer receptiveness to Islamic home financing. Based on 150 usable questionnaires, PLS results indicate that attitude and perceived behavioural control of the TPB are instrumental in determining the receptiveness of Islamic home financing products. Besides, the added factor, namely, perceived customer taqwa is influential in explaining the receptiveness- implying that God-fearing and God-conscious in oneself resulted in strong intention to opt for halal products. The findings demonstrate that the enhancement of measurement items for TPB factors as well as generation of new factor reflecting Islamic home financing are relevant in determining one's decision of Islamic home financing. Besides, the findings could offer support to Islamic bank managers to enhance their planning for Islamic home financing products and develop effective strategies accordingly that benefit their customers.
\end{abstract}

Keywords: Islamic home financing; Theory of Planned Behaviour (TPB); Customer; Taqwa; Malaysia.

\section{INTRODUCTION}

According to the Islamic Finance Development Indicator (IFDI, 2019), the global Islamic banking assets are estimated at USD1.7 trillion as at the end of 2018. In terms of industry growth, Malaysia maintains a leading position worldwide followed by other Muslim countries such as Bahrain, UAE,

\footnotetext{
* Corresponding author: Labuan Faculty of International Finance, Universiti Malaysia Sabah, Labuan International Campus,
} Malaysia, E-mail: khadijahsayuti511@gmail.com 
Pakistan, Saudi Arabia, Jordan, Oman, Kuwait, Brunei and Indonesia (IFDI, 2019). Malaysia's Islamic banking assets are estimated at USD201.4 billion as at the end of 2018, ranked third globally after Iran and Saudi Arabia. The development of Islamic banking and finance today is a clear manifestation of Islam as a religion purports a way of life. The Islamic financial system unites Islamic values with the traditional financial system, with a priority to meet the various needs of modern-day Muslims. This alternative to traditional finance is indeed an attractive plan for both Muslims and non-Muslims owing to the unique features that it offers. Islamic banking and products are uniquely distinct from their conventional peers because of two main reasons. First, Islamic banks have to thrive under strict religious guidelines or the Shariah principles to ensure interest are prohibited in all forms of transactions. It also ensures business activities are fairly conducted for legal (halal) profits. Second, Islamic banking products are developed based on ijtihad (i.e. independent reasoning) with Shariah advisors as to the experts in Islamic banking and finance.

Generally, Islamic home financing shows tremendous growth throughout the years. From the existing 16 Islamic banks under Bank Negara Malaysia (BNM), the amount of Islamic home financing transactions amplified from RM29.8 billion in 2010 to RM131.1 billion as at end of 2017, representing 27.1 per cent to Islamic banking's total financing. This positive trend indicates that Islamic home financing has gained a positive response from the public. Moreover, it is one of the primary reservoirs of profit for the bank along with other financing facilities such as automobile financing, credit cards and others. For instance, Bank Islam Malaysia Berhad (BIMB) has been reported that Islamic home financing contributes more than 50 per cent from total financing's profit for Islamic banks (Amin et al., 2017a).

Various efforts have been Islamic banks engrossed to promote Islamic home financing products, however, the acceptance of the products is still lagging compared with their conventional peers. A current statistic indicates that in the year 2017, the market share of Islamic home financing was 21.2 per cent compared with its conventional counterpart recorded a percentage of 78.8 (BNM, 2018). Customer receptiveness is somewhat a missing dimension in the Islamic home financing products. The customers' significant view is often not prioritised when Islamic banks designed the offered. Consequently, their marketing strategies are somewhat misleading and fallacious.

Against this backdrop, this study considers factors influencing first-time house buyers' intention to choose Islamic home financing products in a Malaysia context.

\section{LITERATURE REVIEW AND HYPOTHESES DEVELOPMENT}

\subsection{Theory of Planned Behaviour}

Theory of Planned Behaviour (TPB) by Ajzen (1991) is drawn from the revision of the Theory of Reasoned Action (TRA) by Ajzen and Fishbein (1980). This theory explains a model in which human action or behaviour is manifested based on his intention. The theory clarifies that human behaviour is a result of a set of beliefs, notably, behavioural beliefs, normative belief and control beliefs. The present study selects TPB. The reasons are three-fold. First, the TPB has a parsimony value (Perugini and Bagozzi, 2001; Sekaran and Bougie, 2016). Parsimony is defined as simplicity in explaining the problem or phenomenon to provide solutions for the problem (Sekaran and Bougie, 2016). The TPB can explain a complex relationship in easy ways. Second, the TPB has 
strong empirical support as it has been extended in various area of studies including social sciences (Amin et al., 2013). The TPB is also considered to be one of the most popular paradigms for investigating behavioural intentions (Tan, 2013). The TPB has been used to study in theory-driven research that includes halal food purchasing, sustainable homes purchasing and online gamers' behaviour. Third, it is suggested that further research should be devoted to providing more recent empirical findings associated with the fundamental theory. The current study adds a new variable to reflect the Islamic values in the TPB.

\subsection{Empirical Works on Islamic Home Financing}

Preceding studies on Islamic home financing in Malaysia focus on four primary aspects of customer behaviour, however, but are not restricted to theory testing, the addition of new measures, theory development and Islamic point of view with theory adaptation. The details are provided as follows.

Firstly, several studies examine Islamic home financing in the context of theory testing (Md Taib et al., 2008; Abdul Razak and Abduh, 2011; Amin et al., 2016). In particular, Md Taib et al. (2008)'s study examines Malaysian customer behaviour in the context of Islamic home financing. The work deliberates the importance of musharakah mutanaqisah as an Islamic home financing alternative product to Malaysia and exposes some of the problems faced in bay' bithaman ajil. Using the TRA, the study finds that attitude and subjective norm are significant to influence people's intention. Moreover, the authors discover that subjective norm has a greater influence on intention. However, the work is a theory-testing as no additional variables are proposed to define behavioural intention in the TRA. Similarly, Md Taib et al. (2008), Abdul-Razak and Abduh (2012) examine the TRA to predict Islamic home financing receptivity in the aspect of musharakah mutanaqisah as the alternative product of bay' bithaman ajil. The authors discovered that attitude and subjective norm are significant in examining customers' willingness to choose such financing product. Md Taib et al. (2008) and Abdul-Razak and Abduh (2012) also share the same argument that subjective norm is the most prevailing factor to influence intention. In contrast, Amin et al. (2014c) extend the TPB to examine the effects of factors on the customers' intention to be a partner in the musharakah mutanaqisah home financing. This theory is gauged using an online survey to 168 bank customers. Results indicate that the factors of attitude, subjective norm and perceived behavioural control are found contributory to the behavioural intention.

Secondly, there are existing studies that have introduced new factors to examine customer receptivity of Islamic home financing (Amin, 2008; Abdul-Razak and Md Taib, 2012; Amin et al., 2017). In more detail, Amin (2008) contributes to a quantitative analysis using a survey approach in examining customer receptivity. The author discloses that Shariah principle, lower monthly payment, transparency practice, interest-free practice, and 100 per cent financing are the most important selection criteria. These factors are mostly not examined in earlier studies in this field. Unlike Amin (2008), Abdul Razak and Md Taib (2012) explore customers' perception on specified types of home financing; bay' bithaman ajil and musharakah mutanaqisah. Several measures such as concept-debt versus equity, method of computation and pricing, Shariah compliance, justice and equality, and promotion of a true spirit of Islam and well-being are examined. The findings reveal that a total of 72 per cent respondents are vexed with high pricing of bay' bithaman ajil home financing which burdening the society at large. They also find that musharakah mutanaqisah home financing is more favourable as its profit and loss sharing feature resulting in greater fairness 
and meets the Maqasid al-Shariah. In the most recent customer research concerning Islamic home financing, Amin et al. (2017) discover that service quality, product choice and Islamic debt policy are instrumental in influencing customer attitude which later affecting Islamic home financing preference.

Thirdly, there are existing studies that have introduced so-called Islamic customer factors with theory adaptation (Alam et al., 2012; Amin et al., 2014b). A study by Alam et al. (2012) explores religiosity as one of the factors that influence the intention of customers to choose Islamic home financing. Aiming at bank customers resided in Klang Valley, this study uses the Theory of Planned Behaviour (TPB) with religiosity as the fourth determinant. The findings suggest that attitude, subjective norms, perceived behavioural control and religiosity are key determinants of customer receptivity. Religiosity is recorded as a second important factor influencing customers' intention. In brief, this study use theory testing approach but adds religiosity to reflect the notion of Islamic customer behaviour. Similar to Alam et al. (2012), Amin et al. (2014b) examine the TPB as an underlying theory. This study further suggests Islamicity of product is significant to determine customer receptivity. More importantly, the study discovers that the factor is the strongest factor influencing bank customers' receptivity towards Islamic home financing products in Kota Kinabalu and Labuan. It argues that the customers tend to choose Islamic home financing if they perceived that riba, gharar, maysir and other prohibited elements are absent from the facility.

Fourthly, there are existing studies on Islamic mortgages where theory development is brought into play (Amin et al., 2014a; Amin, 2017a). Captivatingly, Amin et al. (2014a) revive the Theory of Islamic Customer Behaviour $(\mathrm{T} i \mathrm{CB})$ to examine willingness to consider for Islamic home financing. They argue that conventional theories are insufficient to further examine customer receptivity. Therefore, this study introduces the Maqasid al-Shariah index and religious satisfaction by reviewing literature from prominent Muslim scholars to fit in the context of Islamic home financing. Moreover, this study also proposes that religious satisfaction acts as both mediator and moderator. This is to enhance the knowledge about the strength of religion satisfaction on one's well-being. In brief, this study contributes to a relatively new empirical Islamic framework in predicting customer receptivity in Islamic home financing. The same author further extends the $\mathrm{T} i \mathrm{CB}$ in a study of customer behaviour on Islamic home financing (Amin, 2017a). Partial-Least Squares (PLS) analysis conducted by the study reveals that perceived religiosity on a property, perceived Islamic debt principle and perceived maqasid on homeownership are influential in determining receptivity. In short, Amin et al. (2014a) and Amin (2017a) provide new insights by developing a theory that reflects the Islamic worldview of both customer behaviour and home financing.

\subsection{Factors Affecting First-Time House Buyers' Intention towards Islamic Home Financing}

\section{Attitude}

Attitude refers to the positive or negative reaction of individuals in performing certain behaviour (Fishbein and Ajzen, 1975; Ajzen, 1991). Attitude is a combination of the behavioural beliefs of the individual and the consequences of performing the behaviour whether it will result in a positive or negative outcome. In this case, attitude is defined as the degree of positive or negative response 
of first-time house buyers in choosing Islamic home financing. As a rule of thumb, the higher the extent of attitude measured in a first-time house buyer, the greater is his behavioural intention towards choosing Islamic home financing. Empirical studies have shown the importance of this factor on intention in Islamic home financing (e.g Alam et al., 2012; Amin et al., 2014b; Amin et al., 2014c). For example, Amin et al. (2014b) find that attitude is significantly influenced the Islamic home financing adoption. The researchers clarify that the success in marketing Islamic home financing products depends strongly on how to handle the differences of attitudes between the customers efficiently. Other than that, Amin et al. (2014c) examine attitude as an independent variable towards intention to be a partner amongst bank customers in musharakah mutanaqisah bank financing. The result eventually shows a significant result. Thus, $\mathrm{H}_{1}$ is hypothesised as:

$\mathrm{H}_{1}$ : Attitude has a positive influence on first-time house buyers' intention to choose Islamic home financing product.

\section{Subjective Norm}

Subjective norm refers to the degree of perception of a customer based on what important others think he should or should not perform certain behaviour (Ajzen, 1991). In this regard, if choosing Islamic home financing is seen as socially desirable behaviour, then the customer is more likely to choose such a facility. The significance of people influence is deliberately referred to family, spouse, friends, colleagues and other people who are close to the individual whom may give an impact in his final decision, for instance, choosing Islamic home financing products. Amin et al. (2014b) discover that the greater subjective norm, the more likely the Islamic home financing to be chosen in the future by the bank customers in Kota Kinabalu and Labuan. Another study conducted by Amin et al. (2014c) examines subjective norm as independent variable towards intention to be a partner amongst bank customers in musharakah mutanaqisah bank financing. The result shows a significant outcome. However, a study done by Alam et al. (2012) shows an insignificant result between subjective norms and intention to choose Islamic home financing in Klang Valley. Therefore, $\mathrm{H}_{2}$ is proposed as:

$\mathrm{H}_{2}$ : Subjective norm has a positive influence on first-time house buyers' intention to choose Islamic home financing product.

\section{Perceived Behavioural Control}

Perceived Behavioural Control refers to an individual's perception of easiness or difficulty of performing a behaviour (Ajzen, 1991). It is concerned over the confidence level of how well one can act with their ability. According to Ajzen (1991), perceived behavioural control, conversely, devours two aspects: how much a person has control over behaviour and how confident a person feels about being able to perform or not perform the behaviour. Ajzen (1991) adds that this factor is formed partially based on one's experience and partially based on information that he gained from others. Hence, it is suggested that the more the customer perceives that Islamic home financing is convenient and eligible to him, the more likely he intends to choose Islamic home financing in the future. Many studies have documented the importance of this factor in their research (Amin et al., 2014b; Amin et al., 2013; Alam et al., 2012). For instance, Amin et al. $(2014 b)$ find that perceived behavioural control is significantly influenced the Islamic home financing adoption amongst bank customers in Kota Kinabalu and Labuan. In another area, Klang 
Valley, Alam et al. (2012) prove the significance of the factor in determining Muslim customers' intention to choose Islamic home financing. Therefore, we hypothesise:

$\mathrm{H}_{3}$ : Perceived behavioural control has a positive influence on first-time house buyers' intention to choose Islamic home financing product.

\section{Perceived Customer Taqwa}

Perceived customer taqwa refers to the degree of customers' priorities concerning the consumption of halal products, earning through halal means and his monetary contribution for the sake of Allah. Al-Qaradhawi (2013) emphasizes taqwa as a guardian to hold a Muslim to stand firm on halal boundaries and to prevent himself from doing prohibited activities. One tends to feel fearful and conscious of the consequences in neglecting Allah's commands to be a good Muslim customer. This includes the case of choosing halal products such as Islamic home financing. This is parallel to Khan (1984) as the author describes taqwa as a sense of God-fearing or God-conscious within oneself. People with taqwa are considered the righteous people whereby their motivation is not self-interest, rather, to seek goodness and to increase self-purification from God without worldly desires (Md-Ilyas, 1992). A high level of taqwa can only be attained through active contribution in everyday affairs in this world which lead to social justice and spiritual motivation for both world and Hereafter (Abuznaid, 2009). Though limited, there is a growing number of studies that extend the empirical results of religiosity in determining customer purchasing decision (Rehman and Shabbir, 2010; Alam et al., 2012; Yousaf and Shaukat Malik, 2013). Alam et al. (2012) discover the importance of religiosity in which customers with high religiosity tend to be more disciplined, responsible and matured. Yousaf and Shaukat Malik (2013) suggest that customer behaviour varies with the level of product involvement and level of religiosity. In terms of high involvement product, students with high religiosity tend to be more impulsive, fashion-conscious and socially influenced while shopping than middle and low religious peers. These findings are consistent with the study of Alam et al. (2012). Rehman and Shabbir (2010) aim to examine the relationship between religiosity and new product adoption among Muslim customers. Findings assert that religiosity affects new product adoption among Muslim customers; their belief influence how and what products they adopt. These studies, however, do not examine the effect of taqwa on customer behaviour which warrants further empirical investigations. Therefore, we postulate:

$\mathrm{H}_{4}$ : Perceived customer taqwa has a positive influence on first-time house buyers' intention to choose Islamic home financing product.

Figure 1 depicts our research model. 
Figure 1: The Proposed Research Model

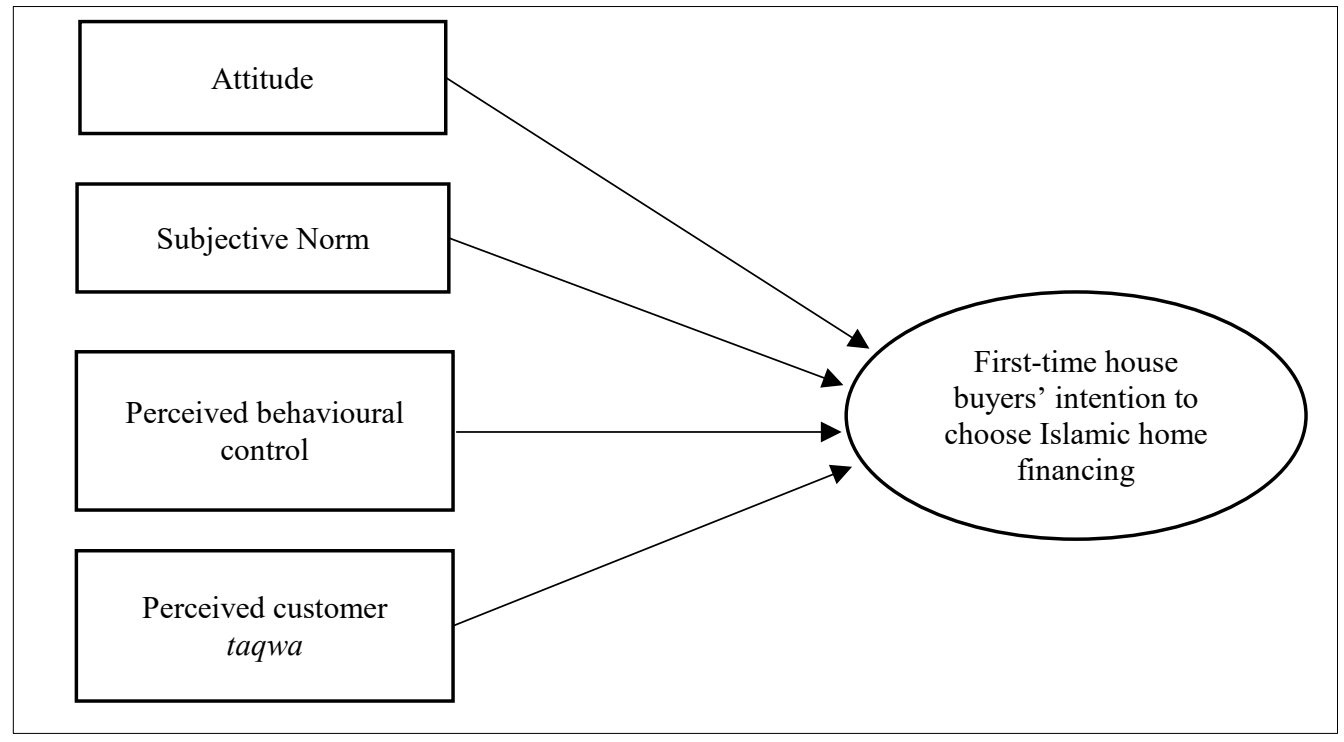

\section{RESEARCH METHODOLOGY}

\subsection{Subject}

The subjects of this study are first-time house buyers. The sample is collected within the area of Kota Kinabalu and Labuan. These two vicinities are selected due to two justifications. Firstly, Kota Kinabalu and Labuan are similar in terms of multi-ethnic culture and strong development for the residential property industry (Amin et al., 2014b). Secondly, Kota Kinabalu and Labuan represent the two states of East Malaysia, Sabah and Sarawak. Indeed, these vicinities are different compared to other cities in West Malaysia due to geography, the standard of living, culture and housing project types (Amin, 2008). As this study could not obtain the official population frame representing the first-time house buyers in Kota Kinabalu and Labuan, hence, Islamic bank customers are selected as alternate respondents. The study selects the sampling frame in three fullfledged Islamic banks situated at Kota Kinabalu and Labuan. These banks are selected as they work on Islamic banking activities only and offer Shariah-compliant financial products including Islamic home financing (Amin, 2008). A total of 200 questionnaires are provided for the survey, of which 150 usable questionnaires are obtained.

This study employs judgemental sampling to select respondents. Judgemental sampling is defined as a non-probability sampling which involves a technique of purposely choosing individuals representing the population based on the researchers' judgement and knowledge (Kothari, 2004). Among the advantages of judgemental sampling is it has a tendency to produce a high response rate or participation level and it is a more realistic approach, provided the sampling criteria are specified (Coviello and Jones, 2004). Those who met these four criteria are selected: 

a) Aged between 25 years old and 35 years old;
b) Existing Islamic bank customers in Kota Kinabalu and Labuan;
c) Those who have never owned a house before but intend to buy one in the future; and
d) Aware of Islamic banking products and services.

Table 1: Profile of Respondents

\begin{tabular}{lccc}
\hline \hline \multicolumn{1}{c}{ Items } & Categories & Frequency & Percentage (\%) \\
\hline \multirow{2}{*}{ Gender } & Male & 58 & 38.7 \\
& Female & 92 & 61.3 \\
\hline \multirow{3}{*}{ Age } & Less than 26 & 66 & 44.0 \\
& $26-30$ & 43 & 28.7 \\
\hline \multirow{2}{*}{ Religion } & $31-35$ & 41 & 27.3 \\
& Muslims & 150 & 100.0 \\
\multirow{3}{*}{ Highest education } & Non-Muslims & 0 & 0.0 \\
attained & SPM & 51 & 34.0 \\
& Diploma & 36 & 24.0 \\
& Degree & 57 & 38.0 \\
& Master & 6 & 4.0 \\
\hline \multirow{2}{*}{ Ethnic } & Malay & 97 & 64.7 \\
& Kadazan Dusun & 7 & 4.7 \\
& Brunei & 2 & 1.3 \\
\hline \hline
\end{tabular}

Note: $\mathrm{N}=150$

\subsection{Measures}

Constructs' items are adapted from previous studies. Attitude is operationalised using five items adapted from Amin et al. (2013) and Amin et al. (2014c). Subjective norm is operationalised using five items adapted from Amin et al. (2013), Amin et al. (2014c) and Amin et al. (2016). Perceived behavioural control is operationalised using five items adapted from Amin et al. (2013) and Amin et al. (2014c). The studies conducted by Md-Ilyas (1992), Alam et al., (2011), Rehman and Shabbir (2010) and Yousaf and Shaukat Malik (2013) are used to generating new measurement items of perceived customer taqwa. The dependent variable (i.e first-time house buyers' intention to choose Islamic home financing) is developed based on Alam et al. (2012) and Amin et al. (2016). A fivepoint Likert scale ranging from "strongly disagree" (1) to "strongly agree" (5) is used to evaluate each statement for all constructs. Three Shariah experts are invited to comment on the measurement of constructs' items (Churchill, 1979). Accordingly, the measurement items are revised. Subsequently, a pilot test is conducted to evaluate the content validities using bank customers who have experience in Islamic mortgage services. A total of 30 actual bank customers rate the measurement items. A final revision is taken to the measurement items. 


\subsection{Method of Analysis}

Before analysing the data, the raw data drawn from the data collection are processed. Questionnaires with incomplete answers are discarded for this purpose. The remaining 150 questionnaires are then coded and keyed in using Statistical Package for Social Science (SPSS). Using SPSS, the current study codes each measurement item based on the variable it belongs to. Furthermore, the profile of respondents is analysed using descriptive statistics to summarize the respondents' traits and characteristics. To examine the significance of developed hypotheses, Partial-Least Squares (PLS) is applied (Ringle et al., 2015). The selection of PLS is due to two reasons. First, PLS is ideal for theory development or when new variables are included in the existing research model (Klejinen et al., 2004). In this case, the current study proposes a new variable into the existing Theory of Planned Behaviour (TPB) namely perceived customer Taqwa. Second, PLS has fewer demands concerning sample size and favourably achieves a higher level of statistical power (Hui and Wold, 1982; Chin and Newsted, 1999; Reinartz et al., 2009; Hair et al., 2012). PLS analysis consists of two stages namely measurement model and structural model (Chin, 2010).

\section{EMPIRICAL RESULTS}

\subsection{Assessment of Measurement Model}

Measurement model analysis is conducted to evaluate the accuracy between the variables and its items. Essentially, it assesses convergent and discriminant validities. Convergent validity is defined as a parameter that measures the extent to which the variables are theoretically related. In this case, factor loadings, composite reliability and average variance extracted (AVE) are reported (Chin, 1998; Chin, 2010; Hair et al., 2016). Factor loadings are a correlation between measurement items and component scores. The loadings are important to determine the items' suitability measured by a certain variable (Chin, 1998). Following Lee and Kozar (2008), factor loadings should be at least 0.707 with no measurement item loading more highly on another factor it aims to measure. As reported in Table 2, all factor loadings are higher than 0.707 , indicating suitable item reliability. Further, composite reliability aims to measure the internal consistency of a variable. The rule of thumb of 0.7 by Chin (1998) is used in this study. In Table 2, all items have composite reliability values which exceed the threshold value of 0.7 , ranging from 0.88 to 0.95 . The average variance extracted (AVE) attempts to measure the amount of variance that the variables can capture. Table 2 demonstrates that all AVE values exceed the recommended value of 0.5 (Fornell and Larcker, 1981). Cronbach's alpha is also reported in this current study. All Cronbach's alpha values are well above the threshold value of 0.7 (Nunnally, 1978). As such, this result indicates that all variables are reliable and suitable in the current research model. 
Table 2: Convergent Validity

\begin{tabular}{|c|c|c|c|c|c|}
\hline Construct & Items & Loadings & $\mathbf{C R}$ & AVE & Cronbach's Alpha \\
\hline \multirow{5}{*}{ Attitude } & ATT1 & 0.823 & \multirow{5}{*}{0.912} & \multirow{5}{*}{0.676} & \multirow{5}{*}{0.878} \\
\hline & ATT2 & 0.850 & & & \\
\hline & ATT3 & 0.830 & & & \\
\hline & ATT4 & 0.708 & & & \\
\hline & ATT5 & 0.888 & & & \\
\hline \multirow{5}{*}{ Intention } & INT1 & 0.877 & \multirow{5}{*}{0.945} & \multirow{5}{*}{0.774} & \multirow{5}{*}{0.927} \\
\hline & INT2 & 0.903 & & & \\
\hline & INT3 & 0.907 & & & \\
\hline & INT4 & 0.858 & & & \\
\hline & INT5 & 0.852 & & & \\
\hline \multirow{4}{*}{ Perceived behavioural control } & PBC1 & 0.881 & \multirow{4}{*}{0.918} & \multirow{4}{*}{0.738} & \multirow{4}{*}{0.877} \\
\hline & $\mathrm{PBC} 2$ & 0.940 & & & \\
\hline & PBC3 & 0.891 & & & \\
\hline & PBC4 & 0.706 & & & \\
\hline \multirow{4}{*}{ Perceived customer taqwa } & PCT1 & 0.798 & \multirow{4}{*}{0.882} & \multirow{4}{*}{0.652} & \multirow{4}{*}{0.820} \\
\hline & PCT2 & 0.843 & & & \\
\hline & РCT3 & 0.870 & & & \\
\hline & PCT4 & 0.709 & & & \\
\hline \multirow{5}{*}{ Subjective norm } & SN1 & 0.904 & \multirow{5}{*}{0.938} & \multirow{5}{*}{0.751} & \multirow{5}{*}{0.917} \\
\hline & SN2 & 0.892 & & & \\
\hline & SN3 & 0.828 & & & \\
\hline & SN4 & 0.906 & & & \\
\hline & SN5 & 0.799 & & & \\
\hline
\end{tabular}

Notes: $\mathrm{AVE}=$ Average Variance Extracted (AVE), $\mathrm{CR}=$ Composite Reliability

Concerning discriminant validity, this study follows the guideline proposed by Chin (2010) in which there exists a discriminant validity problem if the cross-loadings are higher than the factor loadings. Cross loading is defined as a set of an item's loadings which are located outside of its variable. The rule of thumb by Chin (2010) indicates that an item is retained if its factor loading is at least 0.7 and higher than all of its cross-loadings. Overall, the factor loadings in Table 3 are well above the recommended value of 0.7. As for Fornell-Larker criterion, the square root of each variable's AVE value should be higher than the correlations shared between the variables. As presented in Table 4, the square root of each variable's AVE is on the diagonal (in bold values). The non-diagonal values represent the correlations between the variables. Overall, the square roots of the AVEs are all higher than the correlations between the variables. Hence, discriminant validity has been established. 
Table 3: Loadings and Cross-Loadings

\begin{tabular}{cccccc}
\hline \hline Items & ATT & INT & PBC & PCT & SN \\
\hline ATT1 & $\mathbf{0 . 8 2 3}$ & 0.527 & 0.473 & 0.394 & 0.477 \\
ATT2 & $\mathbf{0 . 8 5 0}$ & 0.446 & 0.454 & 0.432 & 0.492 \\
ATT3 & $\mathbf{0 . 8 3 0}$ & 0.530 & 0.488 & 0.366 & 0.513 \\
ATT4 & $\mathbf{0 . 7 0 8}$ & 0.546 & 0.462 & 0.226 & 0.432 \\
ATT5 & $\mathbf{0 . 8 8 8}$ & 0.550 & 0.468 & 0.395 & 0.531 \\
INT1 & 0.652 & $\mathbf{0 . 8 7 7}$ & 0.662 & 0.457 & 0.495 \\
INT2 & 0.555 & $\mathbf{0 . 9 0 3}$ & 0.648 & 0.449 & 0.489 \\
INT3 & 0.595 & $\mathbf{0 . 9 0 7}$ & 0.656 & 0.400 & 0.480 \\
INT4 & 0.506 & $\mathbf{0 . 8 5 8}$ & 0.584 & 0.378 & 0.458 \\
INT5 & 0.479 & $\mathbf{0 . 8 5 2}$ & 0.557 & 0.322 & 0.366 \\
PBC1 & 0.590 & 0.617 & $\mathbf{0 . 8 8 1}$ & 0.344 & 0.527 \\
PBC2 & 0.524 & 0.681 & $\mathbf{0 . 9 4 0}$ & 0.329 & 0.443 \\
PBC3 & 0.468 & 0.591 & $\mathbf{0 . 8 9 1}$ & 0.267 & 0.326 \\
PBC4 & 0.375 & 0.540 & $\mathbf{0 . 7 0 6}$ & 0.175 & 0.302 \\
PCT1 & 0.388 & 0.377 & 0.232 & $\mathbf{0 . 7 9 8}$ & 0.315 \\
PCT2 & 0.373 & 0.304 & 0.242 & $\mathbf{0 . 8 4 3}$ & 0.321 \\
PCT3 & 0.413 & 0.446 & 0.325 & $\mathbf{0 . 8 7 0}$ & 0.353 \\
PCT4 & 0.226 & 0.330 & 0.251 & $\mathbf{0 . 7 0 9}$ & 0.302 \\
SN1 & 0.548 & 0.411 & 0.383 & 0.357 & $\mathbf{0 . 9 0 4}$ \\
SN2 & 0.485 & 0.434 & 0.366 & 0.411 & $\mathbf{0 . 8 9 2}$ \\
SN3 & 0.396 & 0.361 & 0.329 & 0.301 & $\mathbf{0 . 8 2 8}$ \\
SN4 & 0.536 & 0.453 & 0.401 & 0.362 & $\mathbf{0 . 9 0 6}$ \\
SN5 & 0.576 & 0.556 & 0.507 & 0.306 & $\mathbf{0 . 7 9 9}$ \\
\hline \hline
\end{tabular}

Notes: ATT $=$ Attitude, $\mathrm{PBC}=$ Perceived Behavioural Control, $\mathrm{PCT}=$ Perceived Customer Taqwa, INT $=$ Intention to choose Islamic Home Financing

Table 4: Correlations (Latent Variable Correlation Matrix)

\begin{tabular}{cccccc}
\hline \hline Constructs & ATT & INT & PBC & PCT & SN \\
\hline ATT & $\mathbf{0 . 8 2 2}$ & & & & \\
INT & 0.638 & $\mathbf{0 . 8 8 0}$ & & & \\
PBC & 0.574 & 0.710 & $\mathbf{0 . 8 5 9}$ & & \\
PCT & 0.440 & 0.460 & 0.329 & $\mathbf{0 . 8 0 7}$ & \\
SN & 0.597 & 0.524 & 0.470 & 0.402 & $\mathbf{0 . 8 6 7}$ \\
\hline \hline
\end{tabular}

Notes: $\mathrm{ATT}=\mathrm{Attitude}, \mathrm{PBC}=$ Perceived Behavioural Control, $\mathrm{PCT}=$ Perceived Customer Taqwa, INT=Intention to choose Islamic Home Financing

\subsection{Assessment of Structural Model}

To test the significance of hypothesised relationships, assessment on the path coefficients and $\mathrm{R}^{2}$ are necessary. Path coefficients are the estimated strength of relationships between the independent variables and the dependent variable in the model (Hair et al., 2016). $\mathrm{R}^{2}$ is a measure of the model's predictive accuracy. It also describes the extent of variance in the dependent variable explained by 
all independent variables linked to it. In this study, the $\mathrm{R}^{2}$ is 0.613 , signifying that 61.3 per cent of the variance in intention is expounded by attitude, subjective norm, perceived behavioural control and perceived customer taqwa.

Table 5: Hypothesis Testing Results

\begin{tabular}{cccccc}
\hline \hline Hypothesis & Pathway & $\boldsymbol{\beta}$ & t-value & p-values & Supported \\
\hline$H 1$ & $\mathrm{ATT} \rightarrow \mathrm{INT}$ & 0.239 & 3.006 & 0.003 & Yes \\
$H 2$ & $\mathrm{SN} \rightarrow \mathrm{INT}$ & 0.093 & 1.652 & 0.099 & No \\
$H 3$ & $\mathrm{PBC} \rightarrow \mathrm{INT}$ & 0.476 & 7.858 & 0.000 & Yes \\
$H 4$ & $\mathrm{PCT} \rightarrow \mathrm{INT}$ & 0.161 & 2.674 & 0.008 & Yes \\
\hline \hline
\end{tabular}

Notes: $\mathrm{ATT}=$ Attitude, $\mathrm{PBC}=$ Perceived Behavioural Control, $\mathrm{PCT}=$ Perceived Customer Taqwa, INT=Intention to choose Islamic Home Financing

Figure 2. Results of the model

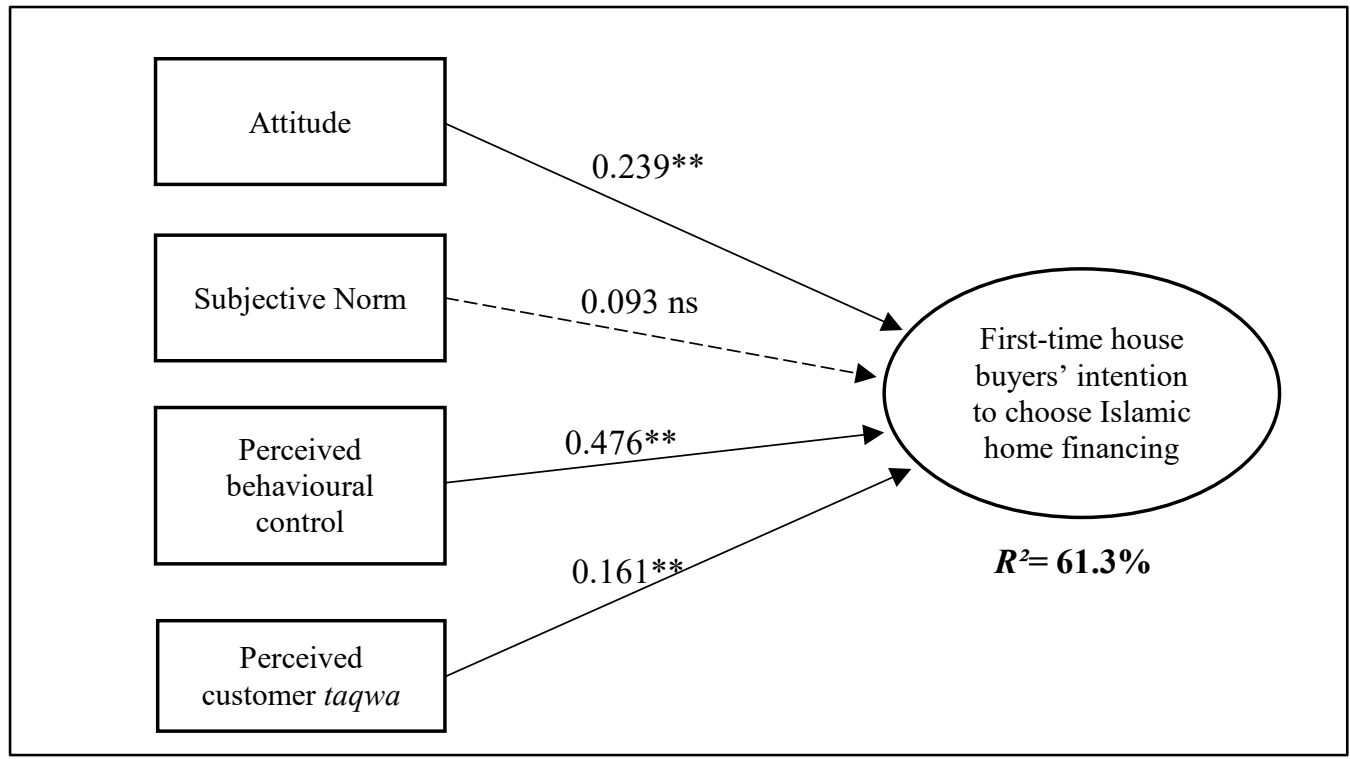

Notes: $\mathrm{ns}=$ not significant, ATT=Attitude, $\mathrm{PBC}=$ Perceived Behavioural Control, $\mathrm{PCT}=$ Perceived Customer Taqwa, $\mathrm{INT}=$ Intention to choose Islamic Home Financing

Table 5 and Figure 2 present the results of the relationships between variables (i.e attitude, subjective norm, perceived behavioural control and perceived customer taqwa) and the first-time house buyers' intention to choose Islamic home financing. It is observed that attitude is positively influencing intention to choose Islamic home financing $(\beta=0.239$, $t$-value $=3.006, p<0.05)$. Hence, $\mathrm{H} 1$ is supported. However, the subjective norm does not influence the intention to choose Islamic home financing $(\beta=0.093$, $\mathrm{t}$-value $=1.652$, ns). Thus, H2 is not supported. Further, perceived behavioural control is significantly associated with intention to choose Islamic home financing ( $\beta=0.476$, t-value $=7.858, \mathrm{p}<0.05$ ). Thus, $\mathrm{H} 3$ is supported. On the other hand, perceived customer taqwa is also proved to be an influential factor in the intention to choose Islamic home financing 
$(\beta=0.161, \mathrm{t}$-value $=2.674, \mathrm{p}<0.05)$. Therefore, $\mathrm{H} 4$ is supported. Of these, perceived behavioural control is the most important predictor to intention followed by attitude and perceived customer taqwa. This result suggests that first-time house buyers are money savvy enthusiasts and wellequipped with financial literacy. Moreover, they have a strong ability in making a firm and wise financial decision especially about whether to choose Islamic home financing or not. In contrast, the subjective norm is found to be not influential in capturing their intention to choose Islamic home financing. One particular reason is that they are keen to make own financial decision without considering others' opinions.

\section{DISCUSSION AND CONTRIBUTIONS}

Emanating from the findings, attitude is significantly related to the first-time home buyers' behavioural intention towards Islamic home financing. The result of attitude is consistent with earlier Malaysian customer acceptance studies in Islamic home financing (e.g Md Taib et al., 2008; Alam et al., 2012; Amin, 2017b). It is believed that an increase in attitude leads to an increase in the Islamic home financing receptivity, implying a positive attitude. It is of utmost importance to recognise a positive attitude as it improves receptiveness and thus the growth. This trend of attitude has a greater impact on one's decision and may even so determine to improve and accelerate demand for Islamic home financing products. Consequently, a proper direction of prospective attitudes of customers should be handled with cautious to create an impact to patronise.

Concerned with perceived behavioural control, the result matches those observed in earlier studies by Alam et al. (2012), Amin et al. (2013) and Amin et al. (2014b) on the important role of perceived behavioural control on Islamic home financing. Furthermore, this factor is found to be the strongest predictor than other examined predictors for the Islamic home financing receptivity. This simply means that the greater the perceived behavioural control, the greater the chance for Islamic home financing to be chosen in the future by first-time house buyers. It is strongly asserted that perceived behavioural control is an answer to uncontrollable fundamentals of behaviour, which are differed from one to another beyond attitude and subjective norm, enabling a better process of belief for improved receptiveness.

Further, the present study finds an insignificant relationship between subjective norm and the receptivity. This outcome is contrary to previous studies which have suggested that opinion voiced by one's family and friends can affect his or her decision to utilise Islamic home financing (Md Taib et al., 2008; Amin et al., 2014b; Amin et al., 2014c; Amin, 2017b). Stimulatingly, the current result corroborates the findings of Alam et al. (2012), which indicate that subjective norm is not associated with Islamic home financing receptivity. A possible explanation for the inconsistent findings may be due to the selected potential first-time house buyers have sufficient information about Islamic banking products especially home financing. Hence, they preferred to make their own decision without considering family and friends' opinion. Although insignificant, the current research extends a new finding concerning subjective norm, yet, produces room for improvement for future research.

Perceived customer taqwa is significantly associated with the receptiveness. This finding further supports the vivid notion of Md-Ilyas (1992) who proposes the development of newly taqwa scales. Moreover, the results support previous research, which links the relationship between religiosity 
and customer behaviour (e.g Rehman and Shabbir, 2010; Alam et al., 2011; Amin et al., 2014a). It can be interpreted in that an improved feeling of God-fearing can jack up the likelihood for the customers to select Islamic home financing products, enabling a value-added role of religiosity in promoting Islamic home financing products. They can be viewed as the best customers in the market as they are highly particular to what they are consuming whether the products are halal and in line with the Shariah. This group is also being extra careful when indulging things that Allah (SWT) forbids (e.g ignorance in paying zakah and sadaqah; earning through haram means). Hence, the higher the extent of perceived customer taqwa, the more positive the customer receptivity towards Islamic home financing products.

\subsection{Theoretical Contributions}

The first theoretical implication that can be drawn from this work is an attempt to close a research gap exists in the literature by understanding the first-time house buyers' receptivity towards Islamic home financing. First-time house buyers are a key stakeholder for Islamic banks that signify the importance of developing Islamic home financing products based on their expectations and demands. Prior studies are merely investigating behavioural intention among potential home buyers, without specifying first-time house buyers or second-time house buyers (e.g Alam et al., 2012; Amin et al., 2013). Second, this study enhances the TPB by including a so-called Islamic version of customer factor namely perceived customer taqwa. The factor is found significantly related to Islamic home financing receptivity. This study offers new theoretical extensions in explaining Islamic home financing receptivity from Islamic worldview. Third, this study proposes an inclusive research model concerning key areas in which Islamic banks can encourage first-time house buyers' intention to choose Islamic mortgages. Figure 3 presents the final and revised research model of this study.

\subsection{Methodological Contributions}

Concerning methodological contributions, this study firstly contributes to the literature by creating new battery items representing perceived customer taqwa. Limited studies are fallen short in introducing such scales into Islamic home financing preference studies (e.g Md Taib et al., 2008; Abdul Razak \& Md Taib, 2011; Alam et al., 2012; Amin et al., 2017). For this purpose, three Shariah experts are invited to define as well as to validate the traits that can best represent the factor. Moreover, this study proves the effectiveness of Partial-Least Squares (PLS) analyses in Islamic home financing context. Prior studies in this area have reported utilising the same type of analyses (e.g Amin et al., 2013; Amin et al., 2016; Amin et al., 2017) and it is reported to be effective and robust. 
Figure 3: The Final Research Model

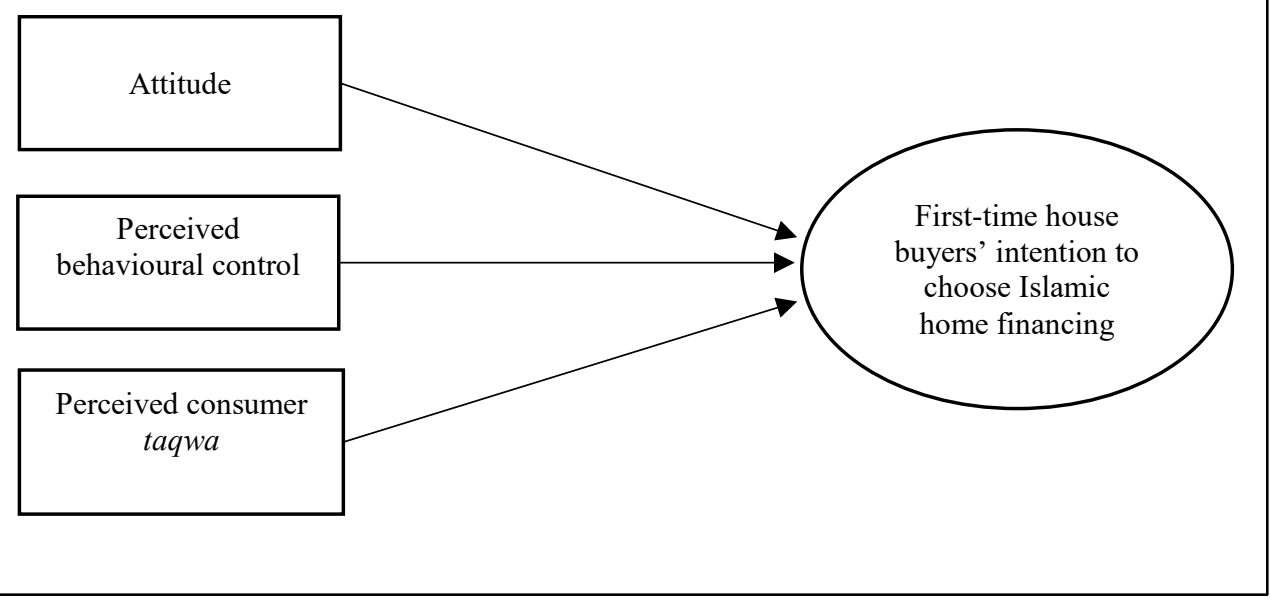

\subsection{Practical Contributions}

This study provides strategies for Islamic banks' managers to enhance the marketability of Islamic home financing. Three factors such as attitude perceived behavioural control and perceived customer taqwa are found to be the essential determinants that can offer better prospects of Islamic mortgages. These factors should be implemented carefully by the bank managers before promoting Islamic home financing to existing and potential first-time house buyers. For instance, this study exposes that customer attitude is associated with Islamic home financing receptivity. It is believed that customers have a different attitude from one another. Therefore, educating the potential firsttime house buyers about the advantages of Islamic home financing products is necessary to inculcate a positive attitude towards such products. One of the approaches for the Islamic banks is to organise periodic events such as "Islamic finance festivals" with the main purpose to elevate the customers' awareness of Islamic home products. The public can be exposed to free counselling programs, forums, financial management workshops and other financial services. With vast knowledge, they become more conversant and this may encourage their positive attitudes towards Islamic banking products, especially Islamic mortgages.

Concerning perceived behavioural control, by giving greater access through useful sources such as Islamic banks' official websites, brochures and other related mediums, the potential first-time house buyers may improve their control in deciding for Islamic home financing. For instance, the bank managers should update their official website from time to time regarding Islamic home financing product disclosure sheets, current rates, latest news and information, fatwa and the like. The bank managers should consistently guide the potential first-time house buyers to decide for their most suitable Islamic home financing. Another strategy is to develop an innovative, userfriendly online application which meant for the customers to contact the bank representatives whenever they are in need. The representatives will provide answers for them within 24 hours. As a result, the customers may feel confident to cope against any problems related to Islamic 
mortgages. The development of such an application may ultimately enhance the sales of the products and enlarges the customer base for Islamic banks.

Relating to perceived customer taqwa, bank managers should take an initiative to plan for future strategies in capturing the divine values instead of commercial values of Islamic home financing products. This indicates that Islamic bank managers should develop the role of perceived customer taqwa through the presence of religious activities which may attract those targeted pious customers to opt for Islamic home financing. These activities should include one-to-one counselling program, debates and outdoor campaigns with a collaboration between relevant religious experts and Islamic bank officers. This may help the Islamic banks to spread valuable insights regarding the importance of Islamic home financing as halal products and blessed by the Almighty. Moreover, the banks should train their representatives on how to handle the pious customers who are mainly cautious of whether one's product or service is halal or haram. Therefore, good interaction between the bank representatives and the customers is the key to increase the customers' perception of taqwa towards Islamic mortgages. The representatives may advise them with respectful and polite that selecting Islamic home financing is not merely a choice, rather, an obligation as a Muslim to his God. They should understand that Islamic home financing is an alternative to the traditional conventional home loans, thus free from interest-based and uncertainty transactions.

\section{CONCLUSION AND FUTURE RESEARCH}

This study has explored some interesting findings in examining Islamic home financing receptivity. The findings show that the proposed research model is practical for understanding Islamic home financing receptivity, thus, providing better directions for the Islamic banks to strengthen the market share of Islamic home financing industry in Malaysia. Likewise, the significant factors are important to improve their products and services and at the same time enhance their competitiveness and profitability against conventional home loans. The current study suggests that future researchers should expand the research to a larger scale of regions to obtain generalisability of the research findings. Considering the comparison between full-fledged Islamic banks and pure conventional banks will also enrich the findings in the context of customer behaviour in Islamic mortgages. Moreover, it would be beneficial if future studies examine other categories of respondents to yield a stronger result that can be generalised to a broader scope of customers. Finally, future studies are anticipated to enhance the theory of Islamic customer behaviour in examining a set of robust Islamic customer factors to predict behavioural intention as well as the suitability of such theory in the context of Islamic mortgage receptivity, at least.

\section{ACKNOWLEDGEMENT}

This study is funded by the Fundamental Research Grant Scheme (FRGS): FRG0438-SS-1/2016, Ministry of Higher Education (MOHE), Malaysia. This work is also part of the Master studies of the first author. All authors contribute equally. 


\section{REFERENCES}

Abdul Razak, D., \& Abduh, M. (2012). Customers' attitude towards diminishing partnership home financing in Islamic banking. American Journal of Applied Sciences, 9(4), 593-599.

Abdul Razak, D., \& M-Taib, F. (2011). Customers' perception of Islamic home financing: Empirical evidence on Bai Bithaman Ajil (BBA) and diminishing partnership (DP) modes of financing in Malaysia. Journal of Islamic Marketing, 2(2), 165-176.

Abuznaid, S. A. (2009). Business ethics in Islam: the glaring gap in practice. International Journal of Islamic and Middle Eastern Finance and Management, 2(4), 278-288.

Ajzen, I. (1991). The theory of planned behaviour. Organizational Behavior and Human Decision Processes, 50(2), 179-211.

Ajzen, I., \& Fishbein, M. (1980). Understanding attitudes and predicting social behaviour. Englewood Cliffs: Prentice-Hall.

Alam, S. S., Janor, H., Zanariah, C. A. C. W., \& Ahsan, M. N. (2012). Is religiosity an important factor in influencing the intention to undertake Islamic home financing in Klang Valley. World Applied Sciences Journal, 19(7), 1030-1041.

Alam, S. S., Mohd, R., \& Hisham, B. (2011). Is religiosity an important determinant on Muslim customer behaviour in Malaysia? Journal of Islamic Marketing, 2(1), 83-96

Al-Qaradhawi, Y. (2013). The lawful and the prohibited in Islam. New York: The Other Press.

Amin, H. (2008). Choice criteria for Islamic home financing: Empirical investigation among Malaysian bank customers. International Journal of Housing Markets and Analysis, 1(3), 256-274.

Amin, H. (2017a). Customer behaviour of Islamic home financing: Investigating its determinants from the theory of Islamic customer behaviour. Humanomics, 33(4), 517-548.

Amin, H. (2017b). Explaining the decision to choose Islamic mortgage financing: The case of East Malaysia. International Journal of Business and Society, 18(S1), 177-192.

Amin, H., Abdul Rahman, A. R., Abdul Razak, D., \& Rizal, H. (2017). Customer attitude and preference in the Islamic mortgage sector: A study of Malaysian customers. Management Research Review, 40(1), 95-115.

Amin, H., Abdul-Rahman, A. R., \& Abdul Razak, D. (2014a). Theory of Islamic customer behaviour: An empirical study of customer behaviour of Islamic mortgage in Malaysia. Journal of Islamic Marketing, 5(2), 273-301.

Amin, H., Abdul-Rahman, A. R., \& Abdul-Razak, D. (2013). An integrative approach for understanding Islamic home financing adoption in Malaysia. International Journal of Bank Marketing, 31(7), 544-573.

Amin, H., Abdul-Rahman, A. R., \& Abdul-Razak, D. (2016). Malaysian customers' willingness to choose Islamic mortgage products: An extension of the theory of interpersonal behaviour. International Journal of Bank Marketing, 34(6), 868-884.

Amin, H., Rahim Abdul Rahman, A., \& Abdul Razak, D. (2014b). Customer acceptance of Islamic home financing. International Journal of Housing Markets and Analysis, 7(3), 307-332.

Amin, H., Rahman, A. R. A., \& Razak, D. A. (2014c). Willingness to be a partner in musharakah mutanaqisah home financing: Empirical investigation of psychological factors. Jurnal Pengurusan (UKM Journal of Management), 40, 69-81.

BNM. (2018). Monthly highlights and statistics. Retrieved from http://www.bnm.gov.my/files/publication/msb/2018/3/ebook_3.pdf

Chin, W. W. (1998). The partial least squares approach to structural equation modelling. Modern Methods for Business Research, 295(2), 295-336. 
Chin, W. W. (2010). How to write up and report PLS analyses. In Handbook of Partial Least Squares (pp. 655-690). Springer, Berlin, Heidelberg.

Chin, W. W., \& Newsted, P. R. (1999). Structural equation modelling analysis with small samples using partial least squares. Statistical Strategies for Small Sample Research, 1(1), 307341.

Churchill Jr, G. A. (1979). A paradigm for developing better measures of marketing constructs. Journal of marketing research, 16(1), 64-73.

Coviello, N. E., \& Jones, M. V. (2004). Methodological issues in international entrepreneurship research. Journal of Business Venturing, 19(4), 485-508.

Fishbein, M., \& Ajzen, I. (1975). Belief, attitude, intention and behavior: An introduction to theory and research. Reading, MA: Addison-Wesley.

Fornell, C., \& Larcker, D. F. (1981). Structural equation models with unobservable variables and measurement error: Algebra and statistics. Journal of Marketing Research, 382-388.

Hair Jr, J. F., Hult, G. T. M., Ringle, C., \& Sarstedt, M. (2016). A primer on partial least squares structural equation modelling (PLS-SEM). Sage Publishing: Thousand Oaks.

Hair, J. F., Sarstedt, M., Ringle, C. M., \& Mena, J. A. (2012). An assessment of the use of partial least squares structural equation modelling in marketing research. Journal of the Academy of Marketing Science, 40(3), 414-433.

Hui, B. S., \& Wold, H. O. A. (1982). Consistency and consistency at large of partial least squares estimates. In K. G. Jöreskog \& H. O. A. Wold (Eds.), Systems under indirect observation, part II (pp. 119-130). Amsterdam: North Holland.

Islamic Finance Development Indicator (2019). Quantitative development indicators. Retrieved from http://www.zawya.com/islamic-finance-development-indicator/\#

Khan, M. F. (1984). Macro-consumption functions in an Islamic framework. Journal of Research in Islamic Economics, 1(2), 1-24.

Kothari, C. R. (2004). Research methodology: Methods and techniques. New Age International.

Lee, Y., \& Kozar, K. A. (2008). An empirical investigation of anti-spyware software adoption: A multi-theoretical perspective. Information \& Management, 45(2), 109-119.

Md-Ilyas, Q. S. (1992). Dimensions of muslim religiosity: Measurement consideration. In Ansari, Z.A. (ed.), Qur'anic concepts of human psyche (pp. 99-114). Institute of Islamic Culture, Islamabad.

Md Taib, F., Ramayah, T., \& Abdul Razak, D. (2008). Factors influencing the intention to use diminishing partnership home financing. International Journal of Islamic and Middle Eastern Finance and Management, 1(3), 235-248.

Nunnally, J. C. (1978). Psychometric theory. McGraw-Hill: Hillsdale, NJ.

Perugini, M., \& Bagozzi, R. P. (2001). The role of desires and anticipated emotions in goal-directed behaviours: Broadening and deepening the theory of planned behaviour. British Journal of Social Psychology, 40(1), 79-98.

Rehman, A. U., \& Shahbaz Shabbir, M. (2010). The relationship between religiosity and new product adoption. Journal of Islamic Marketing, 1(1), 63-69.

Reinartz, W., Haenlein, M., \& Henseler, J. (2009). An empirical comparison of the efficacy of covariance-based and variance-based SEM. International Journal of Research in Marketing, 26(4), 332-344.

Ringle, C. M., Wende, S., \& Becker, J. M. (2015). SmartPLS 3. Retrieved from http://www.smartpls.com

Sekaran, U., \& Bougie, R. (2016). Research methods for business: A skill-building approach. John Wiley \& Sons: West Sussex. 
Tan, T. H. (2013). Use of structural equation modelling to predict the intention to purchase green and sustainable homes in Malaysia. Asian Social Science, 9(10), 181--191.

Yousaf, S., \& Shaukat Malik, M. (2013). Evaluating the influences of religiosity and product involvement level on the customers. Journal of Islamic Marketing, 4(2), 163-186. 